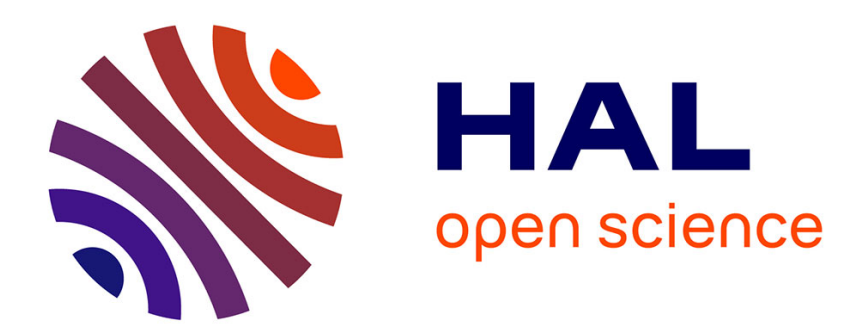

\title{
Business performance and angels presence: a fresh look from France 2008-2011
}

\author{
Luc Tessier, Cécile Fonrouge
}

\section{To cite this version:}

Luc Tessier, Cécile Fonrouge. Business performance and angels presence: a fresh look from France 2008-2011. Small Business Economics, 2017. hal-01555254

\section{HAL Id: hal-01555254 \\ https://hal.science/hal-01555254}

Submitted on 20 Sep 2017

HAL is a multi-disciplinary open access archive for the deposit and dissemination of scientific research documents, whether they are published or not. The documents may come from teaching and research institutions in France or abroad, or from public or private research centers.
L'archive ouverte pluridisciplinaire HAL, est destinée au dépôt et à la diffusion de documents scientifiques de niveau recherche, publiés ou non, émanant des établissements d'enseignement et de recherche français ou étrangers, des laboratoires publics ou privés. 


\title{
Business performance and angels presence: a fresh look from France 2008-2011
}

\author{
Nadine Levratto • Luc Tessier • Cecile Fonrouge
}

Accepted: 10 October 2016

(C) Springer Science+Business Media New York 2017

\begin{abstract}
Business angels enjoy a strong reputation for being more efficient than other investors among policy makers, practitioners, and scholars. However, due to the limited availability of specific financial data, previous research has barely assessed the impact of angels on companies' performance. This paper seeks to bridge this gap by providing evidence from a unique dataset made up of 432 angel-backed French companies which are
\end{abstract}

This research was partially supported by the network France Angels which provided us a list of companies backed by business angels. We thank the members of the expert committee who provided insight and expertise that greatly assisted the research, as well as the participants of the Research Network on Innovation, 2014, who gave us valuable suggestions on an earlier version of this paper. We thank the anonymous reviewers for their valuable comments that greatly improved the manuscript. All the opinions expressed are those of the authors and not those of the France

Angels. The usual disclaimers apply.

Electronic supplementary material The online version of this article (doi:10.1007/s11187-016-9827-5) contains supplementary material, which is available to authorized users.

N. Levratto $(\bowtie)$

CNRS, EconomiX, University Paris Ouest Nanterre La Défense, Bâtiment G, 200 avenue de la République, 92001 Nanterre Cedex, France

e-mail: nadine.levratto@u-paris10.fr

L. Tessier

ERUDITE, University Paris Est Marne-la-Vallée, Bâtiment Bois de l'Etang, 5 boulevard Descartes - Champs/Marne, 75454

Marne- la-Vallée, France

\section{Fonrouge}

Université du Québec à Trois-Rivières, Ecole de Gestion, 1416

Desj-Hydro-Qc, Trois-Rivières, QC G9A 5H7, Canada compared to two control groups, one randomly selected and another one consisting of similar enterprises. This double comparison process enables us to purge our analysis of structural effect and to demonstrate the importance of the methodology in generating the sample. Indeed, the results we obtain significantly differ depending on the control group. Our results show that the positive influence of angels depends on the condition of the comparison. The set of BA-backed companies is more likely to exhibit superior performance when it is compared to a random sample whereas the companies' performance is either identical or worse when it is compared to a sample composed of k-nearest neighbors. In addition, using a quantile regression technique makes it possible to differentiate the effect of business angels based on the distribution of the value of the growth rate.

Keywords Business angels $\cdot$ Equity investors $\cdot$ Firm growth · Quantile estimations

JEL classifications G24 · M13 · C23 · L25 · L26

\section{Introduction}

An intensively debated but still open question in the entrepreneurial finance literature asks to what extent early-stage financiers contribute to bridge the equity gap faced by new technology-based firms and improve the growth and performance of the companies in which they invest (Hechavarría et al., 2016). Among the different players able to provide financing alternative to 
young and innovative companies (Bruton et al. 2015; Bjørgum and Sørheim 2015; Vismara 2016a; Vismara 2016b), business angels (BAs) play a crucial role which motivates the attention paid by the governments to these non-professional investors (OECD 2011). This paper proposes to enlighten the relationship between entrepreneurial finance and growth focusing on the contribution of the BAs to the companies' growth rate.

Business angels comprise a class of private investors who provide risk capital to new and growing businesses in which they have no family connection (Mason and Harrison 1995, 2002; Maula et al. 2005). These investors directly invest their own money, in addition to their time and expertise, in unquoted companies in the hope of financial gains (Mason 2007). The presence of a BA on a board is considered as an advantage for a start-up for several reasons. Firstly, it helps to meet the high financial needs faced before the intervention of venture capitalists (VCs), not interested in relatively small and high-risk investments, secondly, it increases the firm probability of survival, and thirdly, it facilitates the commitment of VCs and other financial investors in the financing of future investments (Huang and Knight 2015; Becker-Blease and Sohl 2015).

Several studies previously showed angels' crucial role as providers of financial resources and as mentors in accompanying young and innovative companies. Their superior efficiency is reflected by a high internal rate of return (Capizzi 2015a, 2015b) but this effect vanishes beyond a threshold (Capizzi 2011). The capacity of experienced BAs to perform better is largely called into question by Heukamp et al. (2007) who show that, when compared to solo investments, co-investments with BAs do not generate higher returns. These doubts are shared by Johnson and Sohl (2012) who, examining the performance of entrepreneurial IPOs, conclude that BA-backed companies have a lower score, whereas Chahine et al. (2007) find no significant difference.

In examining the literature, it is obvious that the advantages of business angel activity remain questionable. The main limit of these studies originates from the selection of a set of companies able to enter into financial markets. The samples considered appear highly biased towards the very best companies and therefore, cannot be considered as representative of the population of companies benefiting from the mentoring and financial support of a BA. For these reasons, much remains to be done to better understand BA influence on business performance (Cumming and Vismara, 2016).
This paper freshly examines the question of whether entrepreneurial financiers affect the growth of companies in which they invest. Indeed, the previous studies leave unresolved the measurement of the net advantage for the firms they back compared to those that are not backed. Our research seeks then to provide evidence in this field by proposing an empirical analysis of the performance observed in BA-backed companies versus that measured in non-supported ones. To assess the advantage of being accompanied by a BA, we consider the company perspective instead of examining the investor return. Thus, we contribute to the assessment of the impact of BAs on the productive system because we focus on the impact of the participation of a BA in a company's equity on company performance instead of considering their return for the investor. Giving priority to the target is an innovative approach, which is uncommon in the existing literature, in so far as we consider three ratios to depict company performance. To conduct this research, and this is the second novelty of the paper, we propose to investigate the differences between BAbacked companies and two control groups. This analysis is possible due to the use of a unique data set containing 432 companies backed by institutional French BAs over the 2004-2011 period and the composition of two counterfactuals composed from datasets of companies whose annual financial statements are made available by the French Tax Administration and the National Institute of Statistics (INSEE). One group has been randomly selected, whereas the other is comprised of nearest neighbors, i.e., similar firms in terms of size, age, industry, location, and capital structure. This double comparison process allows us to purge our analysis of structural effects and to provide evidence regarding the importance of the methodology in composing the sample.

Our results show that being funded by a BA is favorable for companies. The differences in the growth rates observed in the test group significantly vary depending on the control group considered. The set of BAbacked companies is more likely to exhibit superior performance when compared to a random sample, whereas the performance of these companies is, at best, identical when compared to a sample composed of companies presenting the same structural characteristics as the investee ones. When controlled for the profile of the companies, our results show that angels do not significantly permit companies to grow faster.

The remainder of this paper is structured as follows. Section 2 presents the literature on the influence of BAs 
on company growth and defines the main hypotheses tested in our study. Section 3 describes the dataset, and Section 4 describes the econometric strategy adopted accordingly. Section 5 depicts and comments on the results of the empirical analyses. We conclude considering the implications of our findings for policy makers and advisors in the business creation process.

\section{The effect of BA participation on firm's performance and growth}

The literature on business angels considers that their net contribution to economic life is twofold.

According to Macht and Robinson (2009), BAs help overcome funding gaps, fill knowledge and experience gaps, provide contacts and leverage further funding. However, BAs' role is not limited to accompanying nascent companies. As a part of the "funding escalator" system (Gregson et al. 2013), they also determine a company's future and growth path. Due to their similar roles, many scholars consider that BAs will affect business performance in much the same manner as VCs (Davila et al. 2003).

BAs not only provide financial resources to the companies in which they invest. They also actively participate in the monitoring and reorganization of the companies in which they participate (Sapienza and Gupta, 1994; Avdeitchikova and Landström, 2014). Similar to venture capitalists (VCs), BAs monitor, control, and help with recruitment and additional fundraising (Hellmann and Puri 2002). They also mentor the entrepreneur and open access to providers and potential customers due to their network (Macmillan et al. 1989; Bygrave and Timmons, 1992). Politis (2008) also notes that a BA contribution is extended through a variety of hands-on roles ranging from board membership to less structured consulting activities and formalized part-time assignments. This non-financial support makes it possible to significantly improve the performance of angelbacked companies.

The theoretical argument that underlies this positive appreciation on BAs is very similar to the one put at the forefront for VCs. It lies in the agency costs, which has been the dominant concept in explaining the investor-entrepreneur relationship (Kelly and Hay 2001; van Osnabrugge 2000). When an active investor enters a company, he/she behaves similarly to outside stakeholders who carefully observe the firm to track its business potential and monitor agent behavior to protect against opportunism. Thus, information asymmetry may lead to suboptimal choices ex ante; however, a VC typically conducts a due diligence assessment of the venture and the entrepreneur (Tyebjee and Bruno 1984). This assessment is a precautionary measure that reduces the risk of adverse selection. Once the investment has been made, the active monitoring operated by the investor reduces the risk of moral hazard. We could expect these same arguments to apply to the BAentrepreneur relationship. Consequently, BA-backed companies should perform better than non-backed ones.

The relevance of agency theory, rooted in the separation between ownership and control in large corporations (Jensen and Meckling 1976), in the financing of small and early-stage companies has often been contested because such companies are often closely held. However, despite this tight equity structure, information asymmetry remains a valid assumption when investors are non-professional. This is indeed the case with angels who mainly originate from the entrepreneurial world (Gompers and Lerner 2001). This feature is a true disadvantage because it prevents BAs from accessing financial information, understanding the strategic choices of the founding entrepreneur, and assessing the reliability of his or her expectations. Thus, BAs are led to compensate for their lack of knowledge and skills by strengthening their requirements towards the entrepreneur. It takes time for the entrepreneur to comply with these increased requirements, to explain his/her choices, and to justify himself/herself; this is precious time that could perhaps otherwise be devoted to managing the business and seeking new business opportunities. Such coordination problems are likely to degrade the performance of the investee company so that, as noted by Capizzi (2015b) and Van Osnabrugge (2000), firms that have a BA on the board may exhibit lower performance than those without one.

Consequently, this paper analyzes two related questions: the existence of superior economic impact on BAbacked firms and its relation to BA funding. According to the literature, the impact of the hands-on involvement of BAs on the performance of the business remains unclear. If BAs are not involved, their contribution is considered similar to that of VCs. According to the literature, VCs exert influence on sales (Bertoni et al. 
2013), on employee growth (Davila et al. 2003) and, finally for Puri and Zarutskie (2012), on both sales and employment.

To assess the contribution of angels to a company's performance, we act in accordance with Macht and Robinson (2009) who recommend the consideration of several different ratios. This proposal is consistent with the view of practitioners according to whom growth is a complex phenomenon (Achtenhagen et al. 2010), not only reflected by sales or employment growth but one that also requires us to focus on internal development. Thus, in accordance with Murphy et al. (1996) who consider that sales and employment are both satisfying proxies of firm performance, we estimate to what extent being backed by an angel may increase the performance of a company. We successively examine these two ratios, although it has been shown that they can be correlated as shown by Federico and Capelleras (2015) according to young firm growth has a positive impact on profits. Insofar their research demonstrates that the effect of profits on growth is shown not significant, we use these two indicators to capture the different perspectives. To complete this external perspective, we introduce a third ratio, namely the growth of tangible capital assets, which is a factor that approximates the investment and, consequently, the capacity of a firm to extend its market size.

Thus, the first hypothesis to be tested is as follows:

H1: Angel-backed companies are more likely to present higher performance than non-backed ones. H1.a: They exhibit a higher rate of growth of employment.

$H 1 . b$ : They have a higher rate of growth of sales.

H1.c: They present a higher rate of growth of tangible capital assets.

In addition to this first level difference, we introduce a second hypothesis to capture the performance induced by the accompanying process implemented by a BA. The hypothesis is based on Capizzi (2015b) in which the influence on the performance is according to the length of the financial relation. The researcher found that investors who maintain their financial resources in the investee company for more than 3 years are more likely to earn higher returns than investors who hold their investment for less than 3 years. This positive relationship results from the BAs' profile and preference. The BAs mainly invest in the early stage of start-up businesses and at the seed level; thus, they need time to let the investee company develop. Moreover, angels also tend to invest a low portion of their own wealth in entrepreneurial ventures and therefore may accept a longer payback period. Thus, the angels intervene as long-term investors (BeckerBlease and Sohl 2011). To consider this feature, we test a second hypothesis, expressed as

H2: Among the BA-backed companies, those with a long-lasting financing relationship are likely to have greater performance than those with a short financial relationship.

As in the previous hypothesis, performance is approximated by employment, sales, and tangible capital asset rate of growth.

\section{Dataset and variables}

We assess the impact of the support offered by a BA to a company by testing the previous hypotheses on the French case. France is worth studying empirically because the country has one of the most active business angel markets in Europe (OECD 2011). ${ }^{1}$ However, the impact of these equity investor groups on firm performance has been barely tested, and the rare attempts proposed are based on a sample composed solely of IPO firms so that they yield biased results.

\subsection{Data sources and sample composition}

Our dataset is developed from the merging of three datasets, all provided by the French National Institute of Statistics $^{2}$ and one by the network, France Angels. The first dataset ${ }^{3}$ contains the tax report, mainly composed of the balance sheet and the profit and loss statement of any taxable corporate company located in France, which is approximately three million enterprises. The second source is the Register of Businesses and Establishments (REE or Répertoire des Entreprises et des Etablissements), which provides information on the age of the companies. The third source is the LIFI dataset of firms' ownership and foreign financial

\footnotetext{
${ }^{1}$ The Resource online 1 presents some key figures of the different European markets.

${ }^{2}$ Nadine Levratto and Luc Tessier are accreditated by the Statistical Confidentiality Committee (Comité du Secret Statistique), the French body that supervises access to data, for using the databases under strict confidentiality agreements. They are the only authors authorized to access the data.

${ }^{3}$ It is named FARE (Fichier Approché de Résultats d'Entreprises).
} 
linkages. These firms are merged with a list of companies backed by a business angel member of the network France Angels. ${ }^{4}$ In addition to the i.d. number of the companies supported, this dataset provides information regarding the length of the relationship between the company and the BA.

Finally, we are endowed with a sample of 432 enterprises funded by an angel member of the France Angels network for which we have also obtained the entire tax report. This sample represents $73 \%$ of the total number of companies funded by this network over the period. The material on-line 2 presents the sectoral structure of the three samples.

The key issue in identifying the impacts of a BA support on firms' growth path lies in the construction of an appropriate counterfactual intended to mimic what would have occurred if firms had not been backed by a BA. By definition, this counterfactual is unobserved. A first simple approach to estimating the effect of the involvement of a BA in a company is to compare the results of supported companies with a set of nonsupported ones. When the selected companies do not constitute a random sample of the productive system, this simple comparison of outcomes would likely result in over-estimating the effectiveness of the BAs. This statement is indeed the case here. In the review of the literature section, we have consistently shown that supported firms are unlikely to be a random sample of the population of firms. In general, BAs are likely to be smaller, younger, and operating in industries more intensively engaged in innovation activities. To obtain a valid estimate of BAs' impact, this effect of selection must be accounted for. We consider this problem while measuring the magnitude of the bias considering another possibility. The consideration consists of choosing another reference group composed of companies with similar characteristics to those selected by BAs. To do so, we apply the $k$ nearest neighbors method introduced by Weiss and Kulikowski (1991). ${ }^{5}$ The main principle behind this method to construct the counterfactual is to find a large group of non-backed firms who are similar to the backed firms in a series of relevant observable characteristics, which constitute the counterfactual or control group.

\footnotetext{
${ }^{4}$ We thank the members of France Angels for their support to this project and their willingness to share their data.

5 This subset has been composed using a SAS «CAHQUAL » procedure made available by the INSEE (1994). For a more detailed presentation of the SAS procedure used to compose this reference group, refer to online resource 3 .
}

We apply this double comparison principle to assess the net effect of the support provided by BAs composing three populations: one test group consisting of 432 companies supported by a BA and two reference groups. The first is composed of 2160 companies randomly selected from a population of 465,744 companies with 100 employees or less that operate in the market sectors that exclude farm, financial, and rental industries. The second control group contains 2160 similar companies, based on the number of employees, the age, the location, ${ }^{6}$ the industry in which they operate, ${ }^{7}$ and the governance structure. Controlling for investee company characteristics is all the more important that BAs' funding decisions, in addition to be primarily oriented towards small, young, and thus independent companies, are also significantly influenced by industry and location (Berchicci et al. 2011). Using a reference group composed of 5-nearest neighbors controls for the bias resulting from the BA preference system, while moderately emphasizing the risks of a comparison with a randomly selected reference group (Kerr et al. 2011).

\subsection{Measuring firm growth}

The definition of the best index to measure firm growth has long been disputed in the literature. The debates are motivated by a twofold problem. First, as a complex phenomenon, growth can be measured by various criteria. Second, the construction of the index may also influence the result measured. We will examine these two aspects successively.

Sales and employment measures are the most widely used in empirical growth studies (Delmar 1997). The indicator chosen depends on the field covered. Industrial economists mainly use the employment growth rate (Coad 2009), which is also easily accessible and applies to all types of firms. Scholars closer to business administration consider that turnover growth is a better index because it is a key target for the entrepreneurs themselves and is simultaneously closely observed by shareholders and equity investors (Ardichvili et al. 1998). Ahmad and Petersen (2007) state that, whereas gross

\footnotetext{
${ }^{6}$ We adopted the second level of the Nomenclature of Units for Territorial Statistics (NUTS).

${ }^{7}$ To define the industries, we adopt the French Classification system which is strictly equivalent to the European standard classification of productive economic activities (NACE). We took the second level, which consists of headings identified by a two-digit numerical code (divisions).
} 
added value or profits are a highly meaningful growth variable, appropriate data for cross-nation or crossindustry evaluations are rarely available. Conversely, indicators such as market share and physical output can be compared solely within firms or industries with a similar product range (Delmar et al. 2003). In addition to these indicators, Baumol (1962) states that capital assets, which can be expected to be closely related to turnover, are a leading indicator of firm growth and, therefore, are a highly meaningful growth variable. To capture various aspects of the firm growth phenomenon, we use these indicators concurrently.

Thus, the hypotheses are tested using three explained variables: the growth rate of employment, the growth rate of sales, and the growth rate of tangible capital assets. To circumvent the problems of bias towards small companies raised by the use of relative ratios to measure firm growth as a change in the number of employees (VarEmpl), in the annual sales (VarSales), and in the value of tangible capital assets (VarAss), ${ }^{8}$ we compute these growth rates as a mean of annual rates measured by a logarithmic difference to prevent a bias in favor of smaller companies (Coad 2009). We get thus

$\operatorname{VarEmpl}_{i}=\frac{\sum_{1}^{P}\left[\ln \left(\mathrm{Empl}_{i, t}\right)-\ln \left(\mathrm{Empl}_{i, t-1}\right)\right]}{P}$

$\operatorname{VarSales}_{i}=\frac{\sum_{1}^{P}\left[\ln \left(\operatorname{Sales}_{i, t}\right)-\ln \left(\operatorname{Sales}_{i, t-1}\right)\right]}{P}$

$\operatorname{VarAss}_{i}=\frac{\sum_{1}^{P}\left[\ln \left(\operatorname{Ass}_{i, t}\right)-\ln \left(\operatorname{Ass}_{i, t-1}\right)\right]}{P}$

where Empl represents the number of employees, Sales represents the annual sales, and Ass represents the value of tangible capital assets. The index $t-1$ denotes a lagged variable and $P$ is the number of period covered by the analysis, here equals to 3 (2008-2009, 20092010, 2010-2011).

\subsection{Descriptive statistics}

Table 1 provides descriptive statistics for the main explained and explanatory variables. As shown in the table provided in Online Resource 2, it also appears that business angels invest in a large variety of industries, including those with a low level of innovation.

\footnotetext{
${ }^{8}$ Small initial size means that large relative growth is easier to achieve with quite small absolute growth, whereas large initial size demands large absolute growth to achieve high relative growth.
}

However, these BAs tend to be over-represented in the communication industries.

Figure 1 represents the kernel density estimation of the three explained variables (growth rate of employment, of sales, and of tangible assets) for the three populations under review. The distribution of the different growth rates displays a characteristic tent-shaped probability density and appears similar to the Laplace distribution with fat tails. Table 1 presents the main characteristics of the three populations. The correlation matrices (Tables 2 and 3) are available in the Appendix 1.

\section{The empirical model}

To test our first hypotheses, we consider the following empirical equation:

$$
\begin{aligned}
\text { Growth }_{i}= & \alpha+\beta B A_{i}+\gamma_{1} \ln \text { Size }_{i, t 0}+\gamma_{2} \ln \text { Age }_{i, t 0} \\
& +\sum_{k} \gamma_{k} \text { Account }_{i, t 0}+\sum_{j} \delta_{j} S_{j}+\varepsilon_{i}
\end{aligned}
$$

where Growth ${ }_{i, t}$ represents alternatively the average annual growth rates of employment $\left(\operatorname{VarEmpl}_{i}\right)$, of sales $\left(\right.$ VarSales $\left._{i}\right)$, and of tangible capital assets $\left(\operatorname{VarAss}_{i}\right.$ ) computed at the firm level. BA is a dummy variable equal to 1 when a company is backed by a business angel, and 0 otherwise. Account is a vector of accounting ratios. Size represents the firm size defined either by the turnover, the number of employees, or the total of tangible assets depending on the explained variable used, whereas Age is the age of the company computed as the difference between $t$ and the year of foundation of the company. $S$ is a dummy variable that represents the industry within which the company operates $S_{j}, j=\{1, \ldots, 5\}$. These three last variables are introduced to control for the intrinsic characteristics of the firm.

The second hypothesis is tested using Eq. (2), which is similar to the first one, with one major exception. The equation includes an additional variable, Length, to measure the duration of the financial relationship between a company and an angel. The duration is computed as the difference between the first capital injection made by a BA in a company and the final year under study, 2011. The equation measuring the impact of the duration is written as 
Table 1 Descriptive statistics of the main explanatory variables according to the sample

\begin{tabular}{|c|c|c|c|c|c|}
\hline Variable & Observations & Mean & Median & Min. & Max. \\
\hline \multicolumn{6}{|l|}{ BA sample } \\
\hline VarEmpl_0811 & 298 & 0.414 & 0.790 & -3.239 & 2.890 \\
\hline VarSales_0811 & 432 & 1.437 & 3.901 & -15.067 & 14.573 \\
\hline VarAss_0811 & 432 & 0.985 & 2.961 & -16.724 & 13.456 \\
\hline Empl08 & 432 & 7.197 & 13.009 & 0.000 & 128.000 \\
\hline lnEmpl08 & 333 & 1.647 & 1.049 & 0.000 & 4.852 \\
\hline Sales08 & 432 & 650.286 & 2092.912 & 0.001 & $20,243.420$ \\
\hline lnSales08 & 432 & 3.658 & 3.984 & -6.908 & 9.916 \\
\hline Ass08 & 432 & 151.175 & 946.928 & 0.001 & $18,333.575$ \\
\hline $\ln A s s C 08$ & 432 & 2.515 & 3.174 & -6.908 & 9.816 \\
\hline Age & 432 & 3.350 & 2.520 & 1.000 & 19.000 \\
\hline $\ln$ Age & 432 & 0.987 & 0.655 & 0.000 & 2.944 \\
\hline Gr & 432 & 0.220 & 0.415 & 0.000 & 1.000 \\
\hline FinIndep08 & 432 & 136.678 & 2092.698 & 0.000 & $38,433.000$ \\
\hline Sales_Ass_08 & 432 & 123.546 & 1437.855 & 0.000 & $26,430.000$ \\
\hline \multicolumn{6}{|l|}{ Alea sample } \\
\hline VarEmpl_0811 & 767 & 0.019 & 0.540 & -3.970 & 2.398 \\
\hline VarSales_0811 & 2160 & -0.183 & 2.683 & -16.165 & 13.175 \\
\hline VarAss_0811 & 2160 & 0.853 & 3.949 & -17.823 & 12.722 \\
\hline Empl08 & 2160 & 3.383 & 11.458 & 0.000 & 245.000 \\
\hline lnEmpl08 & 931 & 1.274 & 1.131 & 0.000 & 5.501 \\
\hline Sales08 & 2160 & 818.910 & 4180.678 & 0.001 & $98,913.990$ \\
\hline $\ln$ Sales08 & 2160 & 4.220 & 3.053 & -6.908 & 11.502 \\
\hline Ass08 & 2160 & 215.162 & 2243.755 & 0.001 & $55,000.724$ \\
\hline $\ln \mathrm{AssC} 08$ & 2160 & 0.327 & 4.841 & -6.908 & 10.915 \\
\hline Age & 2160 & 6.619 & 5.086 & 1.000 & 20.000 \\
\hline lnAge & 2160 & 1.563 & 0.857 & 0.000 & 2.996 \\
\hline Gr & 2160 & 0.077 & 0.266 & 0.000 & 1.000 \\
\hline FinIndep08 & 2160 & 62.550 & 1980.731 & 0.000 & $88,947.000$ \\
\hline Sales_Ass_08 & 2160 & $16,739.373$ & $251,764.393$ & 0.000 & $11,140,964.000$ \\
\hline \multicolumn{6}{|c|}{ Nearest neighbors sample } \\
\hline VarEmpl_0811 & 817 & 0.056 & 0.570 & -2.639 & 3.166 \\
\hline VarSales_0811 & 2160 & -0.125 & 2.690 & -14.221 & 17.043 \\
\hline VarAss_0811 & 2160 & 0.725 & 3.520 & -13.072 & 15.588 \\
\hline Empl08 & 2160 & 5.455 & 16.711 & 0.000 & 219.000 \\
\hline lnEmpl08 & 1002 & 1.519 & 1.285 & 0.000 & 5.389 \\
\hline Sales08 & 2160 & 1148.274 & 8968.901 & 0.001 & $356,163.520$ \\
\hline lnSales08 & 2160 & 4.405 & 3.053 & -6.908 & 12.783 \\
\hline Ass08 & 2160 & 169.998 & 1512.907 & 0.001 & $58,643.335$ \\
\hline $\ln A s s C 08$ & 2160 & 0.556 & 4.727 & -6.908 & 10.979 \\
\hline Age & 2160 & 6.524 & 5.028 & 1.000 & 20.000 \\
\hline lnAge & 2160 & 1.551 & 0.849 & 0.000 & 2.996 \\
\hline Gr & 2160 & 0.129 & 0.335 & 0.000 & 1.000 \\
\hline FinIndep08 & 2160 & $3.666 e+12$ & $1.704 \mathrm{e}+14$ & 0.000 & $7.920 \mathrm{e}+15$ \\
\hline Sales_Ass_08 & 2160 & $17,550.661$ & $174,129.844$ & 0.000 & $6,146,923.000$ \\
\hline
\end{tabular}

Sources: Insee and France Angels, computations are ours 


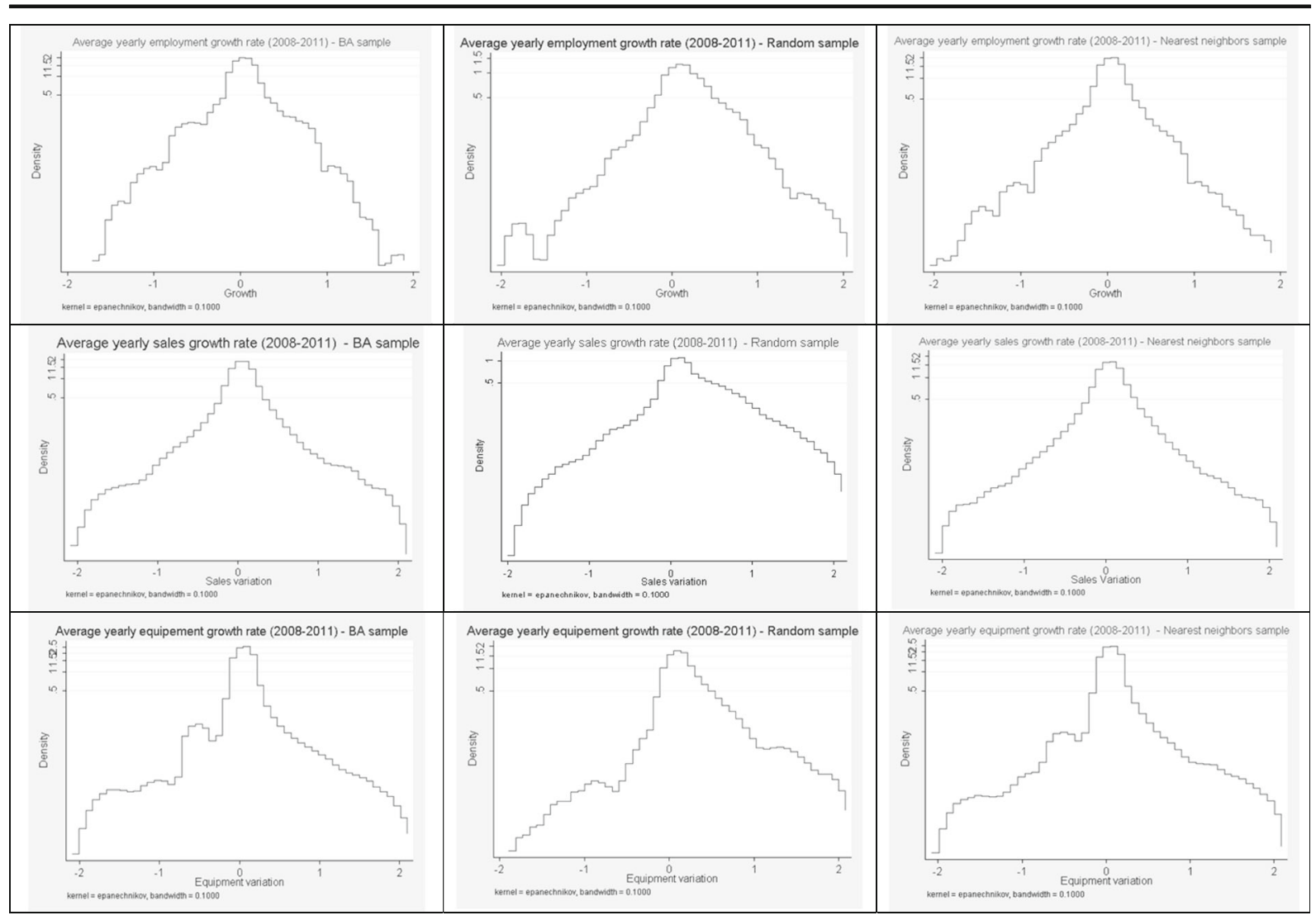

Notes: The Kernel density is computed using Epanenchnikov kernel. Y-axis is on log scale. The graph is estimated using the "kdensity package" available in STATA 12.1 software.

Fig. 1 Kernel density estimation of explanatory variables

$$
\begin{aligned}
\text { Growth }_{i} & =\alpha+\beta \text { Length }_{i}+\gamma_{1} \ln \text { Size }_{i, t 0}+\gamma_{2} \ln _{\text {Age }} \\
& +\sum_{k} \gamma_{k} \text { Account }_{i, t 0}+\sum_{j} \delta_{j} S_{j}+\varepsilon_{i}
\end{aligned}
$$

where the variables have the same definition as in Eq. (1).

We have run the estimations using different techniques. This mix also enables us to test the robustness of our results. The distribution of the explained variables eliminates any possibility of using standard regression estimators that are not robust to outliers and heavy-tailed distributions. In such a case, Coad and Rao (2008) and Coad and Holzl (2012) highlight the superiority of simple QR to estimate a firm growth model. The authors note three main advantages to this technique. First, the technique allows the retention of high growth firms in the sample instead of considering them as outliers and eliminating them. Because the correlation coefficients are estimated along the conditional distribution of the dependent variable, this prevents misleading results caused by the estimation of the average effects of the explanatory variables, as the ordinary OLS method does, when high growth firms remain in the dataset. Second, the QR estimator guarantees the robustness of the estimation results when errors are not normally distributed; this is the case here because growth rate distribution follows a Laplace distribution with fat tails (Fig. 1). Third, QR does not require error terms to be identically distributed at all points of the conditional distribution of the dependent variable. Eliminating this constraint enables us to estimate the effects of the regressors at any point along the distribution of growth rate.

\section{Results and discussion}

This section presents the results of the estimations of the different models using two comparison levels. In the first model, the 432 BA-backed companies, the BA 
sample hereafter, are compared to a randomly selected sample, the random sample below, whereas in the second model, they are compared to a 5-nearest neighbors sample, the neighbor sample below, over the 2008-2011 period. Because of the tent-shaped distribution of the explained variables, the models are estimated using a quantile regression technique. The models have also been estimated by ordinary least squares (OLS) for comparison purposes.

Concerning the first hypothesis, there is a consistent finding that the advantages provided by angels to the investee companies are highly sensitive to the test group. Indeed, we find that BA-backed companies perform better than non-backed ones, solely when they are compared to a randomly selected control group. Conversely, when we compare the test group to a set composed of similar companies (nearest neighbors sample), the advantage primarily disappears. This finding confirms the existence of a selection bias and the need to explain it by assessing the effect of being supported by a BA for a company.

Using quantile regression technique enriches the empirical analysis because it makes it possible to differentiate the impact of BAs along the distribution of the value of the growth rate. This higher degree of precision is of high interest because gazelles are supposed to be the targeted group for BAs.

Because of their superiority noted above, we solely interpret the results provided by the quantile regression estimation technique. Figure 2 presents the estimated coefficients of the presence of a BA on the board as a function of employment, turnover, and tangible asset growth rate distribution. We provide graphs for this variable of interest in the body of the text; the detailed results are presented in the tables provided in the Appendix 2 whereas online resource 4 contents the results of estimated models when the BA sample is compared to the random sample.

\subsection{BA-backed companies do not perform better than non-backed ones}

Our first hypothesis regards the role played by BAs in firm performance. Figure $2 \mathrm{a}-\mathrm{c}$ quantifies the relationship between angel group financing and outcomes when the set of BA-backed companies is compared to a random one, whereas Fig. 3a-c compares the test group to the 5-neareast neighbors set. Examining the value and the significance of the coefficients of the binary variable that depict whether a BA is on the company's board, it is clear that the control population matters in the results obtained (see Table 4, 5 and 6 in the Appendix 2. Tables 2, 3 and 4 contained in the $r$ esource online 4 present the detailed results of the estimations for the comparison between the BA sample and the random sample). BAs' impact on performance is more significant, mainly on sales, when the test population is compared to a random sample than to the nearest neighbors' sample.

Our estimations show that BAs mainly positively contribute to employment growth on the right side of the distribution. This finding confirms our first hypothesis (H1a). Indeed, the estimated coefficients of the dummy variable (Neigh_pop) are positive and significant from the 50th quantile of the conditional distribution of the employment growth, whereas their effect is significantly positive between the 75th and 90th quantile, solely when the comparison is made against a set of nearest neighbors. However, the coefficients' influence depends on the value of the growth rate, as shown by the positive slope of the curve between the 50th (resp. 75th) and the 90th quantiles. This result enables us to consider that BAs demonstrate an entrepreneurial orientation (Lindsay 2004), leading them to facilitate the growth process of the most successful companies.

The difference is stronger when one considers the sales and tangible asset growth rate. Indeed, whereas a growing positive effect is observed when one compares BA-backed companies to the random sample, the coefficients are no longer significant when the test group is compared to the nearest neighbors group. Hypothesis $\mathrm{H} 1 \mathrm{~b}$ is invalidated, whereas $\mathrm{H} 1 \mathrm{c}$ is only confirmed in the central part of the distribution that corresponds to a null growth rate.

Considering the superior robustness of the comparison to a group composed of similar companies, one may consider that our results confirm doubts regarding the capacity of BAs to raise the performance of the companies in which they invest (Cowling et al. 2008; Carpentier and Suret 2013) and the findings from the most recent empirical literature on VCs (Alperovych et al. 2015).

We may also observe that these results contradict the findings of other valuable studies such as those of Ahmed and Cozzarin (2009), Kerr et al. (2011), and Macht and Robinson (2009), which note a positive impact of BAs on the investee companies. 


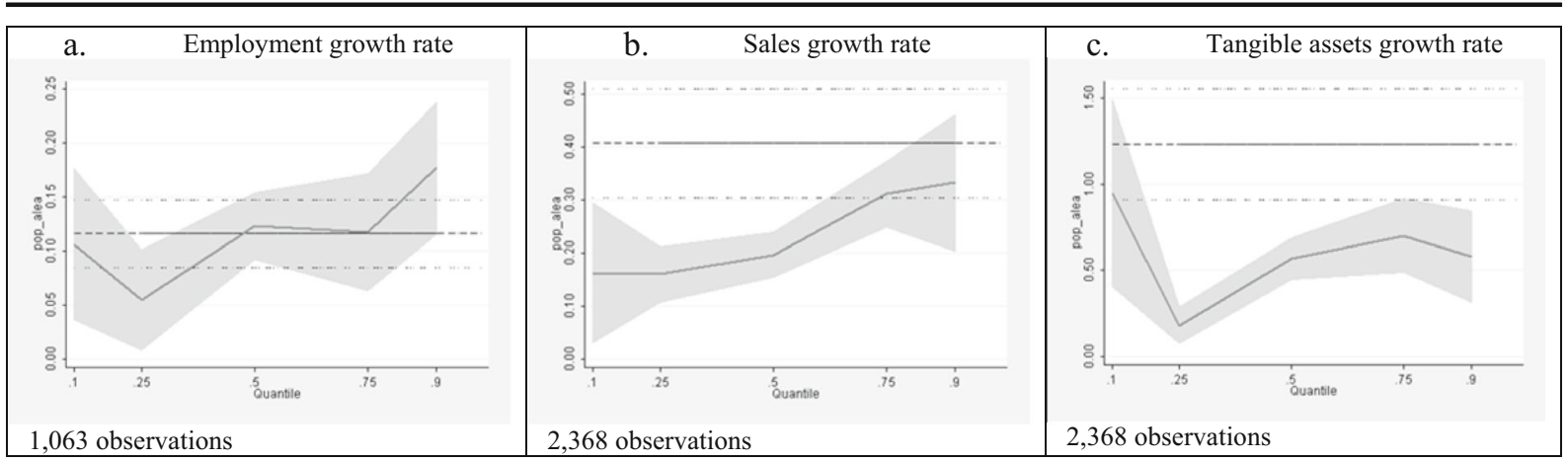

Fig. 2 Estimated coefficients for the Rand pop variable (Q.Reg). The graph shows the values of the estimated coefficient of the Neigh_pop variable as a function of the conditional distribution of the employment, sales, and corporate asset growth rates. The bold, dotted horizontal line is the OLS estimated coefficient. The thin, dashed parallel lines represent the confidence intervals of the fixed-effects estimation. The graph was estimated using the "grqreg" package in STATA 12 software
The methodological difference between these studies and ours may be responsible for these opposite conclusions. Indeed, our empirical analysis is based on the financial and accounting data of companies that operate in different industries. Ahmed and Cozzarin (2009) solely focus on the biotech industry, whereas Kerr et al. (2011) developed their own dataset from the Internet, and, lastly, Macht and Robinson (2009) proceed with nine in-depth telephone interviews.

The results of our estimations also confirm the role of a firm's characteristics in determining employment growth. When measured by the lagged value of the explained variable in the models explaining employment and sale growth rates, initial size (lnEmpl08, InCA08, and InImmC08) presents the usual negative sign. Thus, the reversion to the mean phenomenon, which is often noted in the literature (refer to, among many, Evans 1987; Oliveira and Fortunato 2006; Fagiolo and Luzzi 2006) is confirmed. The variable $\ln$ Age does not have the negative influence currently noted in the literature (refer to Evans 1987 and Navaretti et al. 2014). In most cases, the influence is non-significant and negative on the right extreme of the distribution of the employment growth rate. The accounting variables that depict the financial independence of the company (FinIndep) and the capital rotation rate approximated by Sales_Ass do not determine the firm growth rate when the industry in which it operates is controlled for.

These empirical results lead us to draw several conclusions. First, BAs' support between 2008 and 2011 had only a slightly positive effect on the employment growth rate of French companies. Second, the positive effect of BAs' intervention on firms'

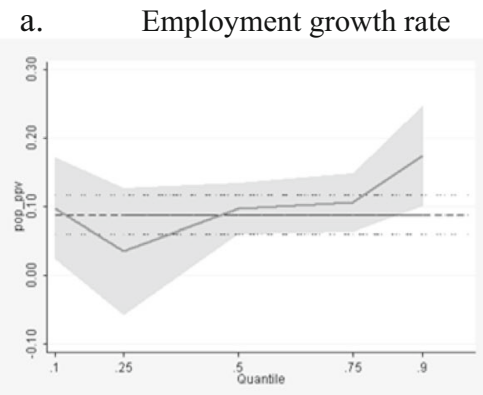

1,115 observations b. Sales growth rate

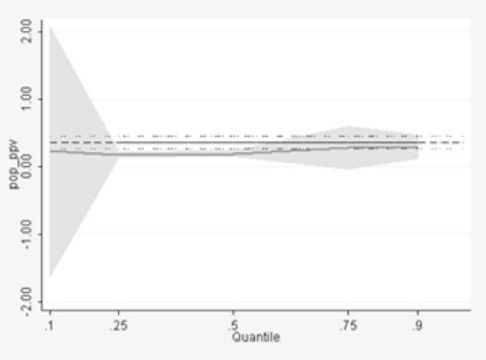

2,444 observations

Fig. 3 Estimated coefficients for the Neigh_pop variable (Q.Reg). The graph shows the values of the estimated coefficient of the Rand pop variable as a function of the conditional distribution of the employment, sales, and corporate asset growth rates. The bold,

c. Tangible assets growth rate

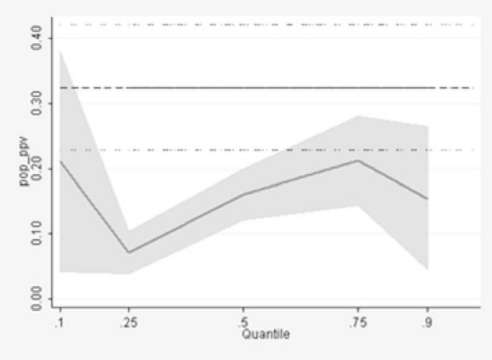

2,444 observations

dotted horizontal line is the OLS estimated coefficient. The thin, dashed parallel lines represent the confidence intervals of the fixed-effects estimation. The graph was estimated using the "grqreg" package in STATA 12 software 
growth rate depends essentially on their economic performance. BAs tend significantly to strengthen the growth rate of firms which are thriving, whereas their effect is null for the companies that experienced decreasing employment. The BAs' influence completely vanishes when firm performance is measured by sales. Finally, the firm growth process is far from being solely explained by the presence of an equity investor on a board of directors. Overall, other characteristics such as size, age, and industry or sector of activity play a role in determining economic performance.

\subsection{The length of the financing relationship does not} matter

This section considers the second hypothesis, according to which, a longer financing relationship enables the backed companies to exhibit higher performance. Figure 4 presents the value of the coefficient of the variable length, measuring the number of years a company has been backed by an angel along the distribution of the firm employment, sales, and tangible asset growth rates. Table 6 in the Appendix 2 provides the detailed results for the comparison between the BA sample and the nearest neighbors population. ${ }^{9}$

When controlled for size, age, and industry, the length of the financial relationship between an angel investor and an investee plays no role in determining the growth rate of the different performance indicators. This result is very contradictory with the idea according to which trust is an asset whose accumulation takes time (Dasgupta 1990); in addition, it contradicts that, during the periods of economic turmoil in particular, investors who have reliable and pertinent information at their disposal are more likely to accompany the investee than outsiders who are hampered by information asymmetry. The advantages of long-term relationships, well established for banks (Guo et al. 2013), have no equivalent in the informal investor market. Indeed, our results do not confirm the positive effect of a long-lasting financial relationship, whatever the growth rate observed and the estimation technique used. Thus, hypothesis 2 is rejected.

\footnotetext{
${ }^{9}$ Tables 5 and 6 contained in the online resource material present the estimation of the models determining employment and sales growth rates according to the length of the financial relationship.
}

This deceiving result echoes certain previous findings in the literature. One possible explanation may be the fact that BAs are not only oriented towards a financial return, but that their motivation is much more complex than that of professional investors and encompasses psychological or emotional aspects (Ibrahim 2008). This statement is contradictory to research papers that show a better return on informal investments made by business angels than those made by non-angels (Riding 2008); however, the control group is radically different because it is composed of ventures backed by non-professional angels.

However, it is difficult to admit that the effects of the ownership structure on the different performance ratios are strictly proportional (Murphy et al. 1996). For example, a growth in sales can be achieved at the cost of reduced firm profitability. Therefore, it is highly unlikely that the use of a single measure of firm performance could sufficiently capture the effects of business angels' hands-on involvement. If BAs are involved, their impact on a firm's performance cannot be strictly similar to those attributable to a VC because BAs are not perfect copies of VCs. As non-professional investors, BAs encounter difficulties in gaining access to financial information (Gompers and Lerner 2001). Consequently, they tend to invest close to home, typically within a day's drive (Freear et al. 2002; Berchicci et al. 2011), and their dealings in sourcing and investing remain a face-toface exercise (Sohl 2006). Being more likely to invest in « gut feeling» (Mason and Harrison 2002, p. 220), BAs are also less investment-efficient.

\section{Conclusion}

This paper investigates whether angel-backed firms exhibit better performance than non-backed ones and the extent to which a longer relationship between an investor and an investee provides an advantage. The results of our empirical exercise partially support our prediction that BAs provide an advantage to the venture in which they invest. This study contributes to research on entrepreneurial with three important results which shed some light on the role played by business angels. Angel-backed firms tend to benefit from BA support when they have higher employment growth rates. This effect is not significant for other firms. Angel-backed 
a. Employment growth rate

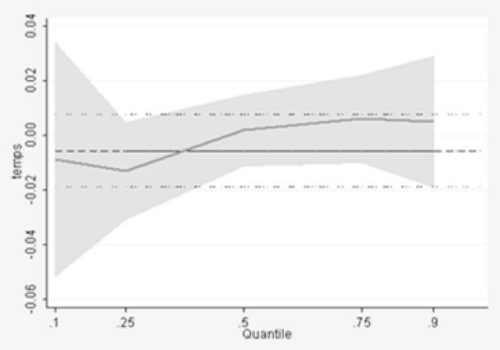

278 observations b. Sales growth rate

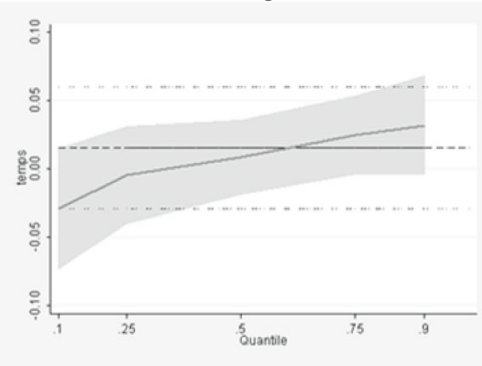

432 observations
Fig. 4 Estimated coefficients for the length variable (Q.Reg). The graph shows the values of the estimated coefficient of the length variable as a function of the conditional distribution of the employment, sales, and corporate asset growth rates. The bold, dotted horizontal line is the OLS estimated coefficient. The thin, dashed parallel lines represent the confidence intervals of the fixed-effects estimation. The graph was estimated using the "grqreg" package in STATA 12 software firms present higher sale growth rates solely in the middle part of the distribution; lastly, angel-backed firms do not systematically invest more than other firms.

The advantage BAs provide is marginal and strictly limited to a small part of the investee companies. This finding may be explained by the fact that BAs are non-professional investors and that their past experience as entrepreneurs does not help them make appropriate choices. A possible explanation lies in their ability to detect the best performers. To some extent, French BAs could present the same limits as European venture capitalists who, according to Bertoni et al. (2016), do not contribute to any positive sorting mechanism mainly because of the tightness of the market. In addition, we find no evidence that a longer financial relationship grants a better result. Possibly, angels are not only motivated by helping firms to grow rapidly but are also interested in strictly financial results or in the psychological benefits of the relationship with an entrepreneur.

The strategy and policy implications of our results are potentially important.

For policy makers, our results imply that institutional BAs do not perform systematically better than other investors. This finding is a serious point to integrate when determining entrepreneurship policies. Indeed, by law, BAs benefit from significant tax rebates to guide idle savings towards promising ventures. The cost of these policies is often considered as disproportionate to their return (Carpentier and Suret 2013; OECD 2011), and the risk of adverse effect is often neglected. Indeed, if it is broadly admitted that granting high net worth individuals greater incentives may increase the number of financial investors, these investors should presumably be providing expertise and contacts in addition to money. First, most programs are open to all informal investors, without consideration of their capacity to provide advice and guidance to start-ups. Second, these programs are not focused on suitable, quality high growth companies, which provide most of the job creation and economic growth effects. Our results present arguments in favor of better-designed programs that are able to select sophisticated investors who seek economic performance more than for tax relief.

Finally, because our study is one of the first attempts to compare the performance of companies backed by a BA with that of a group of similar ones that have not benefited from such support, it naturally notes research issues that need further attention. Among these issues, we add to the research agenda the inclusion of additional sources of finance, such as venture capital or public subsidies, and the need for clearer identification of causal effect. Indeed, following Vismara (2016a), one may consider that the complementarity between angel investors and crowdfunding is a promising field of research. Another serious challenge lies in the lack of data on business angels. The existing data represent a small fraction of the market termed the "visible" market. Although methods of estimating the invisible market, and therefore, the full angel market size, are currently more art than science, it has been demonstrated through various studies over 
the past several years that the total amount of angel investment is likely greater than VC investment. Lastly, our research agenda should also consider behavioral issues more carefully. Indeed, whereas this research solely assesses the advantages possibly provided by the combination of capital injections and accompanying measures, the relationship between a BA and an investee company remains in question. The next stage of this research should then combine quantitative and qualitative data to better depict the reasons why certain investee companies perform better than others.

\section{Appendix 1-Correlation matrices}

Table 2 BA and random samples

\begin{tabular}{|c|c|c|c|c|c|c|c|c|c|c|}
\hline & Growth_0811 & $\operatorname{lnEmp108}$ & $\operatorname{lnSales} 08$ & $\operatorname{lnImmC08}$ & $\ln A g e$ & Gr & pop_alea & $\begin{array}{l}\mathrm{CA}_{-} \\
\mathrm{Immo} \\
\text { moy }\end{array}$ & $\begin{array}{l}\text { Cost } \\
\text { debt } \\
\text { _moy }\end{array}$ & $\begin{array}{l}\text { Indepfi } \\
\text { moy }\end{array}$ \\
\hline Growth_0811_moy & 1.000 & & & & & & & & & \\
\hline $\operatorname{lnEff08}$ & $-0.212^{* * *}$ & 1.000 & & & & & & & & \\
\hline $\operatorname{lnCA} 08$ & $-0.165 * * *$ & $0.409 * * *$ & 1.000 & & & & & & & \\
\hline $\operatorname{lnImmC08}$ & $-0.143 * * *$ & $0.452 * * *$ & $0.465 * * *$ & 1.000 & & & & & & \\
\hline $\ln A g e$ & $-0.248 * * *$ & $0.170 * * *$ & $0.170 * * *$ & $0.086 * * *$ & 1.000 & & & & & \\
\hline Gr & -0.058 & $0.441 * * *$ & $0.198 * * *$ & $0.245 * * *$ & $0.088 * * *$ & 1.000 & & & & \\
\hline pop_alea & $0.278 * * *$ & $0.146^{* * *}$ & $-0.065 * * *$ & $0.174 * * *$ & $-0.251 * * *$ & $0.177 * * *$ & 1.000 & & & \\
\hline CA_Immo_moy & -0.021 & -0.048 & 0.037 & $-0.088 * * *$ & -0.024 & $0.043 *$ & -0.025 & 1.000 & & \\
\hline Cost_debt_moy & -0.040 & -0.013 & $-0.055 * *$ & $-0.041 *$ & $0.041 *$ & 0.003 & 0.001 & -0.004 & 1.000 & \\
\hline Indepfi moy & -0.005 & -0.051 & $-0.113 * * *$ & $-0.107 * * *$ & -0.025 & -0.025 & 0.001 & -0.001 & 0.020 & 1.000 \\
\hline
\end{tabular}

Number of observations $=2076$

The stars indicate the degree of significance (*for $10 \%, * *$ for $5 \%$, and $* * *$ for $1 \%$ )

Table 3 BA and nearest neighbors samples

\begin{tabular}{|c|c|c|c|c|c|c|c|c|c|c|}
\hline & $\begin{array}{l}\text { Growth_- } \\
0811\end{array}$ & $\operatorname{lnEff08}$ & $\operatorname{lnCA08}$ & $\operatorname{lnImmC08}$ & lnAge & $\mathrm{Gr}$ & pop_ppv & $\begin{array}{l}\mathrm{CA}_{-} \\
\mathrm{Immo} \\
\text { moy }\end{array}$ & $\begin{array}{l}\text { Cost_debt } \\
\text { moy }\end{array}$ & $\begin{array}{l}\text { Indepfi } \\
\text { moy }\end{array}$ \\
\hline Growth_0811_moy & 1.000 & & & & & & & & & \\
\hline $\operatorname{lnEff08}$ & $-0.176 * * *$ & 1.000 & & & & & & & & \\
\hline $\operatorname{lnCA} 08$ & $-0.171 * * *$ & $0.445 * * *$ & 1.000 & & & & & & & \\
\hline $\operatorname{lnImmC08}$ & $-0.118 * * *$ & $0.424 * * *$ & $0.470 * * *$ & 1.000 & & & & & & \\
\hline $\ln A g e$ & $-0.279 * * *$ & $0.168 * * *$ & $0.152 * * *$ & $0.044^{*}$ & 1.000 & & & & & \\
\hline Gr & -0.050 & $0.432 * * *$ & $0.171 * * *$ & $0.218^{* * *}$ & $0.097 * * *$ & 1.000 & & & & \\
\hline pop_ppv & $0.246^{* * *} *$ & 0.045 & $-0.086^{* * *}$ & $0.160 * * *$ & $-0.248 * * *$ & $0.096^{* * *}$ & 1.000 & & & \\
\hline CA_Immo_moy & -0.021 & 0.025 & $0.041^{*}$ & $-0.065^{* * *}$ & -0.008 & -0.018 & -0.033 & 1.000 & & \\
\hline Cost_debt_moy & -0.001 & 0.007 & $-0.057 * *$ & $-0.041 *$ & -0.000 & -0.018 & -0.014 & -0.002 & 1.000 & \\
\hline Indepfi_moy & -0.042 & $-0.078 * *$ & $-0.117 * * *$ & $-0.073 * * *$ & 0.024 & 0.032 & -0.011 & -0.002 & $-0.099 * * *$ & 1.000 \\
\hline
\end{tabular}

Number of observations $=2107$

The stars indicate the degree of significance (*for $10 \%, * *$ for $5 \%$, and $* * *$ for $1 \%$ ) 


\section{Appendix 2-Detailed results of the estimations}

Table 4 Estimation of the employment growth rate for the BA and the nearest neighbors samples

\begin{tabular}{|c|c|c|c|c|c|c|}
\hline \multirow[b]{2}{*}{ Variables } & \multirow{2}{*}{$\begin{array}{l}\text { OLS } \\
\text { Empl.* }\end{array}$} & \multicolumn{5}{|c|}{ Quantile regression } \\
\hline & & $\begin{array}{l}10 \% \\
\text { Empl.* }\end{array}$ & $\begin{array}{l}25 \% \\
\text { Empl.* }\end{array}$ & $\begin{array}{l}50 \% \\
\text { Empl.* }\end{array}$ & $\begin{array}{l}75 \% \\
\text { Empl.* }\end{array}$ & $\begin{array}{l}90 \% \\
\text { Empl.* }\end{array}$ \\
\hline lnEmpl08 & $\begin{array}{l}-0.0267 * * * \\
(0.00610)\end{array}$ & $\begin{array}{l}-0.0341 * * \\
(0.0169)\end{array}$ & $\begin{array}{l}-0.0208 * * * \\
(0.00490)\end{array}$ & $\begin{array}{l}-0.00373 \\
(0.00412)\end{array}$ & $\begin{array}{l}-0.0232 * * * \\
(0.00646)\end{array}$ & $\begin{array}{l}-0.0318^{* *} \\
(0.0139)\end{array}$ \\
\hline lnAge & $\begin{array}{l}-0.0545^{* * *} \\
(0.00838)\end{array}$ & $\begin{array}{l}-0.000350 \\
(0.0267)\end{array}$ & $\begin{array}{l}-0.00656 \\
(0.00926)\end{array}$ & $\begin{array}{l}-0.0266^{* *} \\
(0.0127)\end{array}$ & $\begin{array}{l}-0.0750 * * \\
(0.0373)\end{array}$ & $\begin{array}{l}-0.0926 * * * \\
(0.0191)\end{array}$ \\
\hline $\mathrm{Gr}$ & $\begin{array}{l}0.00850 \\
(0.0153)\end{array}$ & $\begin{array}{l}0.0267 \\
(0.0360)\end{array}$ & $\begin{array}{l}0.00701 \\
(0.0111)\end{array}$ & $\begin{array}{l}0.00278 \\
(0.00918)\end{array}$ & $\begin{array}{l}0.00575 \\
(0.0181)\end{array}$ & $\begin{array}{l}-0.00567 \\
(0.0269)\end{array}$ \\
\hline Neigh_pop & $\begin{array}{l}0.0881 * * * \\
(0.0169)\end{array}$ & $\begin{array}{l}0.0972 * \\
(0.0509)\end{array}$ & $\begin{array}{l}0.0344 \\
(0.0251)\end{array}$ & $\begin{array}{l}0.0969^{* * * *} \\
(0.0170)\end{array}$ & $\begin{array}{l}0.106^{* * *} \\
(0.0290)\end{array}$ & $\begin{array}{l}0.173 * * \\
(0.0846)\end{array}$ \\
\hline Sales_AverageAss & $\begin{array}{l}-1.27 \mathrm{e}-08 \\
(1.66 \mathrm{e}-08)\end{array}$ & $\begin{array}{l}-2.49 \mathrm{e}-07 \\
(2.74 \mathrm{e}-07)\end{array}$ & $\begin{array}{l}1.31 \mathrm{e}-08 \\
(0.000873)\end{array}$ & $\begin{array}{l}1.41 \mathrm{e}-09 \\
(8.72 \mathrm{e}-08)\end{array}$ & $\begin{array}{l}-1.09 \mathrm{e}-08 \\
(6.90 \mathrm{e}-08)\end{array}$ & $\begin{array}{l}-2.83 \mathrm{e}-08 \\
(9.84 \mathrm{e}-08)\end{array}$ \\
\hline Interest/debtsAve & $\begin{array}{l}0.000996 \\
(0.00265)\end{array}$ & $\begin{array}{l}-0.00923 \\
(0.0199)\end{array}$ & $\begin{array}{l}0.00832 \\
(0.0495)\end{array}$ & $\begin{array}{l}0.00606 \\
(0.0131)\end{array}$ & $\begin{array}{l}0.00171 \\
(0.806)\end{array}$ & $\begin{array}{l}0.00699 \\
(0.0527)\end{array}$ \\
\hline Manuf & $\begin{array}{l}0.0264 \\
(0.0310)\end{array}$ & $\begin{array}{l}0.0884 \\
(0.0873)\end{array}$ & $\begin{array}{l}-0.000422 \\
(1.031 \mathrm{e}+13)\end{array}$ & $\begin{array}{l}0.0155 \\
(0.0175)\end{array}$ & $\begin{array}{l}0.0656 \\
(0.0796)\end{array}$ & $\begin{array}{l}-0.00915 \\
(0.0574)\end{array}$ \\
\hline Building & $\begin{array}{l}0.000262 \\
(0.0314)\end{array}$ & $\begin{array}{l}0.110 \\
(0.0803)\end{array}$ & $\begin{array}{l}-0.00843 \\
(1.031 \mathrm{e}+13)\end{array}$ & $\begin{array}{l}0.00475 \\
(0.0179)\end{array}$ & $\begin{array}{l}0.0110 \\
(0.0924)\end{array}$ & $\begin{array}{l}-0.0894 \\
(0.0603)\end{array}$ \\
\hline Trade\&Transp. & $\begin{array}{l}0.00716 \\
(0.0296)\end{array}$ & $\begin{array}{l}0.0380 \\
(0.0858)\end{array}$ & $\begin{array}{l}0.00180 \\
(1.031 \mathrm{e}+13)\end{array}$ & $\begin{array}{l}0.0139 \\
(0.0172)\end{array}$ & $\begin{array}{l}0.0397 \\
(0.0924)\end{array}$ & $\begin{array}{l}-0.0183 \\
(0.0564)\end{array}$ \\
\hline Bus. Serv. & $\begin{array}{l}0.0108 \\
(0.0303)\end{array}$ & $\begin{array}{l}0.110 \\
(0.0809)\end{array}$ & $\begin{array}{l}0.00270 \\
(1.031 \mathrm{e}+13)\end{array}$ & $\begin{array}{l}0.00732 \\
(0.0183)\end{array}$ & $\begin{array}{l}0.00856 \\
(0.0610)\end{array}$ & $\begin{array}{l}-0.0381 \\
(0.0716)\end{array}$ \\
\hline Constant & $\begin{array}{l}0.147 * * * \\
(0.0330)\end{array}$ & $\begin{array}{l}-0.207 * * \\
(0.100)\end{array}$ & $\begin{array}{l}0.00451 \\
(1.031 \mathrm{e}+13)\end{array}$ & $\begin{array}{l}0.0506 \\
(0.0343)\end{array}$ & $\begin{array}{l}0.247 * * \\
(0.103)\end{array}$ & $\begin{array}{l}0.449 * * * \\
(0.0608)\end{array}$ \\
\hline Observations & 1063 & 1063 & 1063 & 1063 & 1063 & 1063 \\
\hline R-squared & 0.127 & 0.0269 & 0.0356 & 0.0538 & 0.1333 & 0.1949 \\
\hline
\end{tabular}

Standard errors estimated by the Bootstrap methodology are in parentheses (number of Bootstrap samples $=500$ )

*Empl. stands for the employment growth rate

The stars indicate the degree of significance (*for $10 \%, * *$ for $5 \%$, and $* * *$ for $1 \%$ ) 
Table 5 Estimation of the sales growth rate for the BA and the nearest neighbors samples

\begin{tabular}{|c|c|c|c|c|c|c|}
\hline \multirow[b]{2}{*}{ Variables } & \multirow{2}{*}{$\begin{array}{l}\text { OLS } \\
\text { Sales* }\end{array}$} & \multicolumn{5}{|c|}{ Quantile regression } \\
\hline & & $\begin{array}{l}-10 \% \\
\text { Sales* }\end{array}$ & $\begin{array}{l}25 \% \\
\text { Sales* }\end{array}$ & $\begin{array}{l}50 \% \\
\text { Sales* }\end{array}$ & $\begin{array}{l}75 \% \\
\text { Sales* }\end{array}$ & $\begin{array}{l}90 \% \\
\text { Sales* }\end{array}$ \\
\hline lnSales08 & $\begin{array}{l}-0.125^{* * *} \\
(0.0111)\end{array}$ & $\begin{array}{l}-0.0141 \\
(0.0500)\end{array}$ & $\begin{array}{l}-0.00878^{* * *} \\
(0.00134)\end{array}$ & $\begin{array}{l}-0.0252 * * * \\
(0.00898)\end{array}$ & $\begin{array}{l}-0.125^{* * *} \\
(0.0216)\end{array}$ & $\begin{array}{l}-0.223 * * * \\
(0.0115)\end{array}$ \\
\hline lnAge & $\begin{array}{l}-0.0518 * * \\
(0.0253)\end{array}$ & $\begin{array}{l}0.0757 \\
(0.999)\end{array}$ & $\begin{array}{l}-0.00542 \\
(0.00971)\end{array}$ & $\begin{array}{l}-0.0598 * * * \\
(0.00770)\end{array}$ & $\begin{array}{l}-0.0910^{* * * *} \\
(0.0293)\end{array}$ & $\begin{array}{l}-0.0468^{* *} \\
(0.0217)\end{array}$ \\
\hline Gr & $\begin{array}{l}0.215 * * * \\
(0.0646)\end{array}$ & $\begin{array}{l}0.0293 \\
(1.583)\end{array}$ & $\begin{array}{l}0.00630 \\
(0.0157)\end{array}$ & $\begin{array}{l}0.0305 \\
(0.0255)\end{array}$ & $\begin{array}{l}0.293 * * * \\
(0.0963)\end{array}$ & $\begin{array}{l}0.532 * * * \\
(0.0518)\end{array}$ \\
\hline Neigh_pop & $\begin{array}{l}0.355 * * * \\
(0.0535)\end{array}$ & $\begin{array}{l}0.228 \\
(0.500)\end{array}$ & $\begin{array}{l}0.178 * * * \\
(0.0252)\end{array}$ & $\begin{array}{l}0.193 * * * \\
(0.0225)\end{array}$ & $\begin{array}{l}0.283 * * * \\
(0.0751)\end{array}$ & $\begin{array}{l}0.299 * * * \\
(0.0794)\end{array}$ \\
\hline Sales_AverageAss & $\begin{array}{l}1.69 \mathrm{e}-07 * * * \\
(3.33 \mathrm{e}-08)\end{array}$ & $\begin{array}{l}2.31 \mathrm{e}-08 \\
(3.39 \mathrm{e}-06)\end{array}$ & $\begin{array}{l}3.82 \mathrm{e}-08 \\
(7.09 \mathrm{e}-08)\end{array}$ & $\begin{array}{l}1.81 \mathrm{e}-08 \\
(8.64 \mathrm{e}-08)\end{array}$ & $\begin{array}{l}1.21 \mathrm{e}-07 \\
(7.90 \mathrm{e}-08)\end{array}$ & $\begin{array}{l}1.29 \mathrm{e}-07 * \\
(6.87 \mathrm{e}-08)\end{array}$ \\
\hline Interest/debtsAve & $\begin{array}{l}-0.00174 * \\
(0.000914)\end{array}$ & $\begin{array}{l}0.000891 \\
(3.382)\end{array}$ & $\begin{array}{l}0.000125 \\
(0.00147)\end{array}$ & $\begin{array}{l}-0.000610 \\
(0.00192)\end{array}$ & $\begin{array}{l}-0.00332 \\
(1.388)\end{array}$ & $\begin{array}{l}-0.00613 \\
(0.0143)\end{array}$ \\
\hline Manuf & $\begin{array}{l}0.0340 \\
(0.0923)\end{array}$ & $\begin{array}{l}-0.0887 \\
(4.432 \mathrm{e}+14)\end{array}$ & $\begin{array}{l}-0.0214 \\
(0.0329)\end{array}$ & $\begin{array}{l}0.00205 \\
(0.0243)\end{array}$ & $\begin{array}{l}0.123 \\
(3.234 \mathrm{e}+12)\end{array}$ & $\begin{array}{l}0.201 * * \\
(0.0824)\end{array}$ \\
\hline Building & $\begin{array}{l}0.00913 \\
(0.0885)\end{array}$ & $\begin{array}{l}0.00931 \\
(4.432 \mathrm{e}+14)\end{array}$ & $\begin{array}{l}-0.00345 \\
(0.0300)\end{array}$ & $\begin{array}{l}-0.00504 \\
(0.0241)\end{array}$ & $\begin{array}{l}0.0677 \\
(3.234 \mathrm{e}+12)\end{array}$ & $\begin{array}{l}0.209 * * \\
(0.0913)\end{array}$ \\
\hline Trade\&Transp. & $\begin{array}{l}-0.0153 \\
(0.0806)\end{array}$ & $\begin{array}{l}-0.0771 \\
(4.432 \mathrm{e}+14)\end{array}$ & $\begin{array}{l}-0.0141 \\
(0.0311)\end{array}$ & $\begin{array}{l}0.00173 \\
(0.0237)\end{array}$ & $\begin{array}{l}0.0850 \\
(3.234 \mathrm{e}+12)\end{array}$ & $\begin{array}{l}0.163 * \\
(0.0844)\end{array}$ \\
\hline Bus. Serv. & $\begin{array}{l}-0.156^{*} \\
(0.0840)\end{array}$ & $\begin{array}{l}-0.294 \\
(4.432 \mathrm{e}+14)\end{array}$ & $\begin{array}{l}-0.0691 * * \\
(0.0334)\end{array}$ & $\begin{array}{l}-0.0322 \\
(0.0236)\end{array}$ & $\begin{array}{l}0.0115 \\
(3.234 \mathrm{e}+12)\end{array}$ & $\begin{array}{l}0.00199 \\
(0.0805)\end{array}$ \\
\hline Constant & $\begin{array}{l}0.636^{* * *} \\
(0.0953)\end{array}$ & $\begin{array}{l}-0.371 \\
(4.432 \mathrm{e}+14)\end{array}$ & $\begin{array}{l}-0.0453 \\
(0.0345)\end{array}$ & $\begin{array}{l}0.260 * * * \\
(0.0518)\end{array}$ & $\begin{array}{l}0.929 \\
(3.234 \mathrm{e}+12)\end{array}$ & $\begin{array}{l}1.602 * * * \\
(0.117)\end{array}$ \\
\hline Observations & 2444 & 2444 & 2444 & 2444 & 2444 & 2444 \\
\hline R-squared & 0.200 & 0.0147 & 0.0145 & 0.0385 & 0.1670 & 0.3968 \\
\hline
\end{tabular}

Standard errors estimated by the bootstrap methodology are in parentheses (number of Bootstrap samples $=500$ )

The stars indicate the degree of significance (*for $10 \%, * *$ for $5 \%$, and $* * *$ for $1 \%$ )

*Sales stands for the sales growth rate 
N. Levratto et. al.

Table 6 Estimation of the tangible asset growth rate for the BA and the nearest neighbors samples

\begin{tabular}{|c|c|c|c|c|c|c|}
\hline \multirow[b]{2}{*}{ Variables } & \multirow{2}{*}{$\begin{array}{l}\text { OLS } \\
\text { Assets* }\end{array}$} & \multicolumn{5}{|c|}{ Quantile regression } \\
\hline & & $\begin{array}{l}-10 \% \\
\text { Assets* }\end{array}$ & $\begin{array}{l}25 \% \\
\text { Assets* }\end{array}$ & $\begin{array}{l}50 \% \\
\text { Assets* }\end{array}$ & $\begin{array}{l}75 \% \\
\text { Assets* }\end{array}$ & $\begin{array}{l}90 \% \\
\text { Assets* }\end{array}$ \\
\hline $\ln A s s 08$ & $\begin{array}{l}-0.0853^{* * *} \\
(0.00604)\end{array}$ & $\begin{array}{l}-0.0296^{* * *} \\
(0.00431)\end{array}$ & $\begin{array}{l}-0.00381 \\
(0.0272)\end{array}$ & $\begin{array}{l}-0.00107 \\
(0.00116)\end{array}$ & $\begin{array}{l}-0.0453 * * * \\
(0.0153)\end{array}$ & $\begin{array}{l}-0.197 * * * \\
(0.00811)\end{array}$ \\
\hline $\ln$ Age & $\begin{array}{l}-0.0568^{* *} \\
(0.0251)\end{array}$ & $\begin{array}{l}0.0698^{*} \\
(0.0362)\end{array}$ & $\begin{array}{l}2.23 \mathrm{e}-06 \\
(0.0682)\end{array}$ & $\begin{array}{l}-0.0234 * * * \\
(0.00622)\end{array}$ & $\begin{array}{l}-0.111 * * * \\
(0.0150)\end{array}$ & $\begin{array}{l}-0.0540 * \\
(0.0306)\end{array}$ \\
\hline $\mathrm{Gr}$ & $\begin{array}{l}0.232 * * * \\
(0.0550)\end{array}$ & $\begin{array}{l}0.0196 \\
(0.0308)\end{array}$ & $\begin{array}{l}-0.00430 \\
(0.122)\end{array}$ & $\begin{array}{l}0.00471 \\
(0.00943)\end{array}$ & $\begin{array}{l}0.102 * * * \\
(0.0374)\end{array}$ & $\begin{array}{l}0.458 * * * \\
(0.0713)\end{array}$ \\
\hline Neigh_pop & $\begin{array}{l}0.325 * * * \\
(0.0479)\end{array}$ & $\begin{array}{l}0.211 * * * \\
(0.0818)\end{array}$ & $\begin{array}{l}0.0713 \\
(0.121)\end{array}$ & $\begin{array}{l}0.160 * * * \\
(0.0199)\end{array}$ & $\begin{array}{l}0.212 * * * \\
(0.0341)\end{array}$ & $\begin{array}{l}0.154 * * * \\
(0.0486)\end{array}$ \\
\hline Sales_AverageAss & $\begin{array}{l}-6.28 \mathrm{e}-07 * * * \\
(8.39 \mathrm{e}-08)\end{array}$ & $\begin{array}{l}-5.74 \mathrm{e}-07 * * * \\
(1.86 \mathrm{e}-07)\end{array}$ & $\begin{array}{l}-4.34 \mathrm{e}-07^{*} \\
(2.51 \mathrm{e}-07)\end{array}$ & $\begin{array}{l}-3.90 \mathrm{e}-07 * \\
(2.07 \mathrm{e}-07)\end{array}$ & $\begin{array}{l}-4.91 \mathrm{e}-07 \\
(4.44 \mathrm{e}-07)\end{array}$ & $\begin{array}{l}-5.82 \mathrm{e}-07 \\
(4.19 \mathrm{e}-07)\end{array}$ \\
\hline Interest/debtsAve & $\begin{array}{l}-0.00102 * \\
(0.000538)\end{array}$ & $\begin{array}{l}0.000159 \\
(0.00443)\end{array}$ & $\begin{array}{l}-8.58 \mathrm{e}-06 \\
(0.993)\end{array}$ & $\begin{array}{l}-6.50 \mathrm{e}-05 \\
(0.00129)\end{array}$ & $\begin{array}{l}-0.00123 \\
(0.00506)\end{array}$ & $\begin{array}{l}-0.00489 \\
(0.0190)\end{array}$ \\
\hline Manuf & $\begin{array}{l}0.279 * * * \\
(0.0907)\end{array}$ & $\begin{array}{l}0.00891 \\
(0.0592)\end{array}$ & $\begin{array}{l}0.0257 \\
(9.452 \mathrm{e}+13)\end{array}$ & $\begin{array}{l}0.0157 \\
(0.0114)\end{array}$ & $\begin{array}{l}0.0986^{* * *} \\
(0.0377)\end{array}$ & $\begin{array}{l}0.196^{* *} \\
(0.0833)\end{array}$ \\
\hline Building & $\begin{array}{l}0.105 \\
(0.0923)\end{array}$ & $\begin{array}{l}-0.0436 \\
(0.236)\end{array}$ & $\begin{array}{l}0.00416 \\
(9.452 \mathrm{e}+13)\end{array}$ & $\begin{array}{l}0.00389 \\
(0.00970)\end{array}$ & $\begin{array}{l}0.00175 \\
(0.0394)\end{array}$ & $\begin{array}{l}-0.0680 \\
(0.0842)\end{array}$ \\
\hline Trade\&Transp. & $\begin{array}{l}0.165 * * \\
(0.0792)\end{array}$ & $\begin{array}{l}-0.000674 \\
(0.0428)\end{array}$ & $\begin{array}{l}-4.68 \mathrm{e}-06 \\
(9.452 \mathrm{e}+13)\end{array}$ & $\begin{array}{l}0.00629 \\
(0.00931)\end{array}$ & $\begin{array}{l}0.00624 \\
(0.0364)\end{array}$ & $\begin{array}{l}-0.0565 \\
(0.0813)\end{array}$ \\
\hline Bus. Serv. & $\begin{array}{l}0.0680 \\
(0.0818)\end{array}$ & $\begin{array}{l}-0.0268 \\
(0.0527)\end{array}$ & $\begin{array}{l}-5.91 \mathrm{e}-06 \\
(9.452 \mathrm{e}+13)\end{array}$ & $\begin{array}{l}-0.000873 \\
(0.00929)\end{array}$ & $\begin{array}{l}-0.00687 \\
(0.0412)\end{array}$ & $\begin{array}{l}-0.0870 \\
(0.0783)\end{array}$ \\
\hline Constant & $\begin{array}{l}0.0915 \\
(0.0852)\end{array}$ & $\begin{array}{l}-0.370 * * * \\
(0.0960)\end{array}$ & $\begin{array}{l}-0.0220 \\
(9.452 \mathrm{e}+13)\end{array}$ & $\begin{array}{l}0.0637 * * * \\
(0.0177)\end{array}$ & $\begin{array}{l}0.488 * * * \\
(0.0695)\end{array}$ & $\begin{array}{l}1.261 * * * \\
(0.0898)\end{array}$ \\
\hline Observations & 2444 & 2444 & 2444 & 2444 & 2444 & 2444 \\
\hline R-squared & 0.156 & 0.0431 & 0.0078 & 0.0257 & 0.0709 & 0.3256 \\
\hline
\end{tabular}

Standard errors estimated by the Bootstrap methodology are in parentheses (number of Bootstrap samples $=500$ )

The stars indicate the degree of significance (*for $10 \%, * *$ for $5 \%$, and $* * *$ for $1 \%$ )

*Assets stand for the tangible assets growth rate

\section{References}

Achtenhagen, L., Naldi, L., \& Melin, L. (2010). « Business growth "do practitioners and scholars really talk about the same thing? Entrepreneurship, Theory and Practice, 34(2), 289316.

Ahmad, N., \& Petersen, D. R. (2007). High-growth enterprises and gazelles - preliminary and summary sensitivity analysis. Paris: OECD-FORA http://www.oecd.org/std/businessstats/39639605.pdf. Accessed 12 September 2016.

Ahmed, S., \& Cozzarin, B. P. (2009). Start-up funding sources and biotechnology firm growth. Applied Economics Letters, 16(13), 1341-1345.

Alperovych, Y., Hübner, G., \& Lobet, F. (2015). How does governmental versus private venture capital backing affect a firm's efficiency? Evidence from Belgium. Journal of Business Venturing, 30(4), 508-525.

Ardichvili, A., Cardozo, S., Harmon, S., \& Vadakath, S. (1998). Towards a theory of new venture growth. Proceedings of the 1998 Babson Entrepreneurship Research Conference, Ghent, Belgium. Resource document. Babson.edu. http://fusionmx. babson.edu/entrep/fer/papers98/XIV/XIV_D/XIV_D.html. Accessed 12 September 2016.

Avdeitchikova S., \& Landström H. (2014) The economic significance of business angels - towards comparable indicators, the ratio institute, working paper no. 248. Forthcoming in Landström, H. and Colin Mason (Eds.), Handbook of research on business angels. Cheltenham: Edward Elgar.

Baumol, W. J. (1962). On the theory of expansion of the firm. The American Economic Review, 52(5), 1078-1087. 
Becker-Blease, J. R., \& Sohl, J. E. (2015). New venture legitimacy: the conditions for angel investors. Small Business Economics, 45(4), 735-749.

Becker-Blease, J. R., \& Sohl, J. E. (2011). The effect of gender diversity on angel group investment. Entrepreneurship Theory and Practice, 35, 709-733. doi:10.1111/j.15406520.2010.00391.x.

Berchicci, L., Block, J.H., \& Sandner, Ph.G. (2011). The influence of geographical proximity and industry similarity in a business angel's investment choice. SSRN, doi: 10.2139/ssrn.1964618.

Bertoni, F., D'Adda, D., \& Grilli, L. (2016). Cherry-picking or frog-kissing? A theoretical analysis of how investors select entrepreneurial ventures in thin venture capital markets. Small Business Economics, 46(3), 391-405.

Bertoni, F., Colombo, M. G., \& Grili, L. (2013). Venture capital investor type and the growth mode of new technology-based firms. Small Business Economics, 40(3), 527-552.

Bjørgum, Ø., \& Sørheim, R. (2015). The funding of new technology firms in a pre-commercial industry - the role of smart capital. Technology Analysis \& Strategic Management, 27(3), 249-266.

Bruton, G., Khavul, S., Siegel, D., \& Wright, M. (2015). New financial alternatives in seeding entrepreneurship: microfinance, crowdfunding, and peer-to-peer innovations. Entrepreneurship Theory and Practice, 39(1), 9-26.

Bygrave, W. D., \& Timmons, J. A. (1992). Venture capital at the crossroads. Cambridge: Harvard Business School Press.

Capizzi, V. (2015a). The returns of business angel investments and their major determinants. Venture Capital, 17(4), 271-298.

Capizzi, V. (2015b). Selecting the functional forms of the determinants of the performance of business angels' investments: an empirical analysis of the Italian Informal Venture Capital Market. SSRN, doi: 10.2139/ssrn.2200383.

Capizzi, V. (2011). What drives the returns of business angels' investments? An empirical analysis of the Italian Informal Venture Capital Market. Global Science and Technology Forum (GSTF). Resource document. SSRN. http://papers. ssrn.com/sol3/papers.cfm?abstract id=1930181. Accessed 12 September 2016.

Carpentier, C., \& Suret, J.-M. (2013). Les incitatifs fiscaux pour les anges investisseurs. Revue fiscale canadienne, 61(1), 79157.

Chahine, S., Filatotchev, I., \& Wright, M. (2007). Venture capitalists, business angels, and performance of entrepreneurial IPOs in the UK and France. Journal of Business Finance Accounting, 34(3-4), 505-528.

Coad, A. (2009). The growth of firms: a survey of theories and empirical. Cheltenham: Edward Elgar.

Coad, A., \& Holzl, W. (2012). Firm growth: empirical analysis. In M. Dietrich \& J. Krafft (Eds.), Handbook on the economics and theory of the firm. Cheltenham: Edward Elgar.

Coad, A., \& Rao, R. (2008). Innovation and firm growth in hightech sectors: a quantile regression approach. Research Policy, 37(4), 633-648.

Cowling, M., Bates, P., Jagger, N., \& Murray G. (2008) Study of the impact of Enterprise Investment Scheme (EIS) and Venture Capital Trusts (VCT) on company performance, HM Revenue \& Customs Research Report, 44, Institute for Employment Studies, Brighton (UK). Resource document. https://ore.exeter.ac.uk/repository/bitstream/handle/10036 /67875/hmrc44.pdf?sequence $=1$. Accessed 12 September 2016.

Cumming, D. J. \& Vismara, S. (2016). De-segmenting research in entrepreneurial finance. Venture Capital. An International Journal of Entrepreneurial Finance. Forthcoming.

Davila, A., Foster, G., \& Gupta, M. (2003). Venture capital financing and the growth of startup firms. Journal of Business Venturing, 18(6), 689-708.

Dasgupta, P. (1990). Trust as a commodity. In D. Gambetta (Ed.), Trust: making and breaking cooperative relations (pp. 4972). England: Blackwell Publishers.

Delmar, F. (1997). Measuring growth: methodological considerations and empirical results. In R. Miettinen \& A. Donckels (Eds.), Entrepreneurship and SME research: on its way to the new millenium (pp. 62-86). England: Ashgate.

Delmar, F., Davidsson, P., \& Gartner, W. (2003). Arriving at the high-growth firm. Journal of Business Venturing, 18, 189216.

Evans, D. S. (1987). The relationship between firm growth, size and age: estimates for 100 manufacturing industries. Journal of Industrial Economics, 35(4), 567-581.

Fagiolo, G., \& Luzzi, A. (2006). Do liquidity constraints matter in explaining firm size and growth? Some evidence from the Italian manufacturing industry. Industrial and Corporate Change, 15(1), 1-39.

Federico, J. S., \& Capelleras, J.-L. (2015). The heterogeneous dynamics between growth and profits: the case of young firms. Small Business Economics, 44(2), 231-253.

Freear, J., Sohl, J. E., \& Wetzel, W. (2002). Angles on angels: financing technology-based ventures - a historical perspective. Venture Capital, 4(4), 275-287.

Gompers, P., \& Lerner, J. (2001). The venture capital revolution. The Journal of Economic Perspectives, 15(2), 145-168.

Gregson, G., Mann, S., \& Harrison, R. (2013). Business angel syndication and the evolution of risk capital in a small market economy: evidence from Scotland. Managerial Decision Economics, 34(2), 95-107.

Guo, Y., Holland, J., \& Kreander, N. (2013). Establishing bankcorporate relationships and building competitive advantages. Journal of Financial Services Marketing, 18(1), 27-39.

Hechavarría, D. M., Matthews, C. H., \& Reynolds, P. D. (2016). Does start-up financing influence start-up speed? Evidence from the panel study of entrepreneurial dynamics. Small Business Economics, 46(1), 137-167.

Hellmann, T., \& Puri, M. (2002). Venture capital and the professionalization of start-up firms: empirical evidence. The Journal of Finance, 57(1), 169-197.

Heukamp, F. H., Liechtenstein, H., \& Wakeling, N. (2007). Do business angels alter the risk-return equation in early stage investments? Journal of Private Equity, 10(3), 67-86.

Huang, L., \& Knight, A. (2015) Resources and relationships in entrepreneurship: an exchange theory of the development and effects of the entrepreneur-investor relationship. Academy of Management Review, doi:10.5465 /amr.2014.0397

Ibrahim, D. (2008). The (not so) puzzling behavior of angel investors. Vanderbilt Law Review, 6, 1405-1452.

Jensen, M. C., \& Meckling, W. H. (1976). Theory of the firm: managerial behavior, agency costs and ownership structure. Journal of Financial Economics, 3(4), 305-360. 
Johnson, W. C., \& Sohl, J. (2012). Angels and venture capitalists in the initial public offering market. Venture Capital, 14(1), $27-42$.

Kelly, P., \& Hay, M. (2001). Helping hand or watchful eye? An agency theory perspective on private investor involvement in entrepreneurial ventures. Paper presented at the BabsonKaufman Research Conference, Jonkoping, Sweden. Resource document. Babson.edu. http:/fusionmx.babson. edu/entrep/fer/Babson2001/XXI/XXIB/XXIB.htm. Accessed 12 September 2016.

Kerr, W. R., Lerner, J., \& Schoar, A. (2011). The consequences of entrepreneurial finance: evidence from angel financings. Review of Financial Studies, 27(1), 20-55.

Lindsay, N. J. (2004). Do business angels have an entrepreneurial orientation? Venture Capital, 6(2/3), 197-210.

Macht, S., \& Robinson, J. (2009). Do business angels benefit their investee companies? International Journal of Entrepreneurial Behaviour \& Research, 15(2), 187-208.

Macmillan, I. C., Kulow, D. M., \& Khoylian, R. (1989). Venture capitalists' involvement in their investments: extent and performance. Journal of Business Venturing, 4(1), 27-47.

Mason, C. M. (2007). Informal sources of venture finance. The life cycle of entrepreneurial ventures international. In S. Parker (Ed.), Handbook series on entrepreneurship (Vol. 3, pp. 259299). New York: Springer.

Mason, C. M., \& Harrison, R. T. (2002). Is it worth it? The rates of return from informal venture capital investments. Journal of Business Venturing, 17(3), 211-236.

Mason, C. M., \& Harrison, R. T. (1995). Closing the regional equity gap: the role of informal venture capital. Small Business Economics, 7(2), 153-172.

Maula, M., Autio, E., \& Arenius, P. (2005). What drives microangel investments? Small Business Economics, 25(5), 459475.

Murphy, G. B., Trailer, J. W., \& Hill, R. C. (1996). Measuring research performance in entrepreneurship. Journal of Business Research, 36(1), 15-23.
Navaretti, G. B., Castellani, D., \& Pieri, F. (2014). Age and firm growth. Evidence from three European countries. Small Business Economics, 43(4), 823-837.

OECD (2011). Financing high-growth firms: the role of angel investors, OECD Publishing. doi: 10.1787/9789264118782-en.

Oliveira, B., \& Fortunato, A. (2006). Firm growth and liquidity constraints: a dynamic analysis. Small Business Economics, 27(2-3), 139-156.

Politis, D. (2008). Business angels and value added: what do we know and where do we go? Venture Capital, 10(2), 127-147.

Puri, M., \& Zarutskie, R. (2012). On the life cycle dynamics of venture-capital and non-venture-capital-financed firms. The Journal of Finance, 67(6), 2247-2293.

Riding, A. L. (2008). Business angels and love money investors: segments of the informal market for risk capital. Venture Capital, 10(4), 355-369.

Sapienza, H. J., \& Gupta, A. K. (1994). Impact of agency risks and task uncertainty on venture capitalist-CEO relations. Academy of Management Journal, 37(6), 1618-1632.

Sohl, J. E. (2006). Angel investing: changing strategies during volatile times. Journal of Entrepreneurial Finance, 11(2), 27-47.

Tyebjee, T. T., \& Bruno, A. V. (1984). A model of venture capitalist investment activity. Management Science, 30, 1051-1066.

Van Osnabrugge, M. (2000). A comparison of business angel and venture capitalist investment procedures: an agency theorybased analysis. Venture Capital, 2(2), 91-109.

Vismara, S. (2016a). Equity retention and social network theory in equity crowdfunding. Small Business Economics, 46(4), 579-590.

Vismara, S. (2016b). Information cascades among investors in equity crowdfunding. Entrepreneurship Theory and Practice. Forthcoming.

Weiss, S. M., \& Kulikowski, C. A. (1991). Computer systems that learn. San Mateo, CA: Morgan Kaufmann. 